\title{
Membrane Domains Based on Ankyrin and Spectrin Associated with Cell-Cell Interactions
}

\author{
Vann Bennett and Jane Healy \\ Howard Hughes Medical Institute, and Departments of Cell Biology and Biochemistry, Duke University Medical \\ Center, Durham, North Carolina 27710 \\ Correspondence: v.bennett@cellbio.duke.edu
}

Nodes of Ranvier and axon initial segments of myelinated nerves, sites of cell-cell contact in early embryos and epithelial cells, and neuromuscular junctions of skeletal muscle all perform physiological functions that depend on clustering of functionally related but structurally diverse ion transporters and cell adhesion molecules within microdomains of the plasma membrane. These specialized cell surface domains appeared at different times in metazoan evolution, involve a variety of cell types, and are populated by distinct membrane-spanning proteins. Nevertheless, recent work has shown that these domains all share on their cytoplasmic surfaces a membrane skeleton comprised of members of the ankyrin and spectrin families. This review will summarize basic features of ankyrins and spectrins, and will discuss emerging evidence that these proteins are key players in a conserved mechanism responsible for assembly and maintenance of physiologically important domains on the surfaces of diverse cells.

Spectrins are flexible rods 0.2 microns in Slength with actin-binding sites at each end (Shotton et al. 1979; Bennett et al. 1982) (Fig. 1A). Spectrins are assembled from $\alpha$ and $\beta$ subunits, each comprised primarily of multiple copies of a 106-amino acid repeat (Speicher and Marchesi 1984). In addition to the canonical 106-residue repeat, $\beta$ spectrins also have a carboxy-terminal pleckstrin homology domain (Zhang et al. 1995; Macias et al. 1994) and tandem amino-terminal calponin homology domains (Bañuelos et al. 1998), whereas $\alpha$ spectrins contain an Src homology domain 3 (SH3) site (Musacchio et al. 1992), a calmodulin-binding site (Simonovic et al.
2006), and EF hands (Travé et al. 1995) (Fig. 1A). Spectrin $\alpha$ and $\beta$ subunits are assembled antiparallel and side-to-side into heterodimers, which in turn are associated head-to-head to form tetramers (Clarke 1971; Shotton et al. 1979; Davis and Bennett 1983) (Fig. 1A). In human erythrocytes, in which spectrin was first characterized (Marchesi and Steers 1968; Clarke 1971), actin oligomers containing 10-14 monomers are each linked to five to six spectrin tetramers by accessory proteins to form a geodesic domelike structure that has been resolved by electron microscopy (Byers and Branton 1985). The principal proteins at the spectrin-actin junction are protein 4.1,

Editors: W. James Nelson and Elaine Fuchs

Additional Perspectives on Cell Junctions available at www.cshperspectives.org

Copyright (C) 2009 Cold Spring Harbor Laboratory Press; all rights reserved; doi: 10.1101/cshperspect.a003012

Cite this article as Cold Spring Harb Perspect Biol 2009;1:a003012 
A

$\alpha$ Spectrins

$\alpha \mathbf{I}$

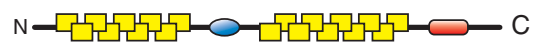

$\alpha$ II

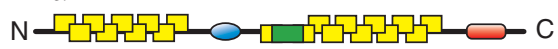

$\beta$ Spectrins

$\beta$ I, II, III and IV

$\mathrm{N} \longrightarrow \mathrm{\square}$

$\beta \vee(B \mathrm{H})$

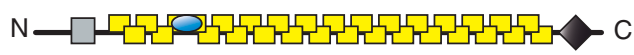

B

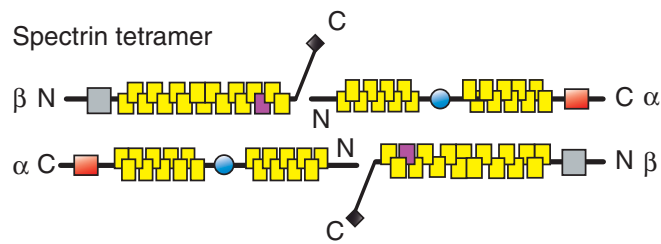

C Ankyrins

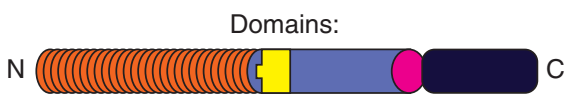

\begin{tabular}{l}
$\square$ Spectrin repeat \\
$\square$ Ankyrin binding repeat \\
$\square$ SH3 Domain \\
$\square \quad$ Calcium binding EF hand domain \\
$\square \quad$ Calmodulin binding site \\
$\square \quad$ Actin binding domain \\
$\square \quad$ Pleckstrin homology domain \\
\hline
\end{tabular}

Figure 1. Domain structure and variants of spectrin and ankyrin proteins. $(A)$ Molecular domains of spectrins: Two $\alpha$ spectrins and five $\beta$ spectrins are shown. Spectrins are comprised of modular units called spectrin repeats (yellow). Other domains such as the ankyrin binding domain (purple), Src-homology domain 3 (SH3, blue), EF-hand domain (red), and calmodulin-binding domain (green) promote interactions with binding targets important for spectrin function. The pleckstrin homology domain (black) promotes association with the plasma membrane and the actin binding domain (grey) tethers the spectrin-based membrane skeleton to the underlying actin cytoskeleton. (B) The spectrin tetramer, the fundamental unit of the spectrin-based membrane skeleton. The spectrin repeat domains of $\alpha$ and $\beta$ spectrin associate end-to-end to form heterodimers. Heterodimers associate laterally in an antiparallel fashion to form tetramers. The tetramers can then associate end-to-end to form extended macromolecules that link into a geodesic dome shape directly underneath the plasma membrane. $(C)$ Molecular domains present in canonical ankyrins. The membrane binding domain of ankyrin isoforms (orange) is comprised of 24 ANK repeats. The spectrin binding domain (green-blue) allows ankyrins to coordinate integral membrane proteins to the membrane skeleton. The death domain (pink) is the most highly conserved domain. The regulatory domain (brown) is the most variable region of ankyrins. The regulatory domain interacts intramolecularly with the membrane binding domain to modulate ankyrin's affinity for other binding partners. All ankyrins and spectrins are subject to alternative splicing, which further increases their functional diversity.

adducin, tropomyosin, tropomodulin, and dematin (Bennett and Baines 2001) (Table 1).

Spectrin is coupled to the inner surface of the erythrocyte membrane primarily through association with ankyrin, which is in turn linked to the cytoplasmic domains of the anion exchanger (Bennett 1978; Bennett and
Stenbuck 1979a,b) and Rh/RhAG ammonium transporter (Nicolas et al. 2003). The spectrinbased membrane skeleton and its connections through ankyrin to membrane-spanning proteins are essential for survival of erythrocytes in the circulation, and mutations in these proteins result in hereditary hemolytic anemia 
Membrane Domains Based on Ankyrin

Table 1. Binding partners of spectrin and ankyrins

\begin{tabular}{|c|c|c|c|}
\hline \multicolumn{4}{|l|}{ Spectrin Binding Partners } \\
\hline Alpha & \multicolumn{3}{|l|}{ Beta } \\
\hline Transporters/ion channels & \multicolumn{3}{|l|}{ Membrane anchors } \\
\hline EnNaC (sodium) & \multicolumn{3}{|l|}{ PI lipids } \\
\hline NHE2 (ammonium) & \multicolumn{3}{|l|}{ Band 4.1} \\
\hline & \multicolumn{3}{|l|}{ Ankyrin } \\
\hline & \multicolumn{3}{|l|}{ EAAT4 (glutamate) } \\
\hline Membrane receptors & \multicolumn{3}{|l|}{ Signaling } \\
\hline NMDA receptor & \multicolumn{3}{|l|}{ RACK-1 } \\
\hline Signaling & \multicolumn{3}{|l|}{ Cytoskeleton/cellular transport } \\
\hline $\mathrm{HsSH} 3 \mathrm{pb} 1$ & \multicolumn{3}{|l|}{ F-actin } \\
\hline Calmodulin & \multicolumn{3}{|l|}{ Adducin } \\
\hline & \multicolumn{3}{|l|}{ Dynactin } \\
\hline \multicolumn{4}{|l|}{ Ankyrin Binding Partners } \\
\hline Membrane BD & Spectrin BD & DD & REG D \\
\hline Ion channels: & Spectrin & FasL & Hsp40 \\
\hline Anion exchanger & & & Obscurin \\
\hline $\mathrm{Na}+/ \mathrm{K}+$ ATPase & & & PP2A \\
\hline \multicolumn{4}{|l|}{ Voltage-gated } \\
\hline \multicolumn{4}{|l|}{$\mathrm{Na}+$ channels } \\
\hline \multicolumn{4}{|l|}{$\mathrm{Na}+/ \mathrm{Ca}^{2+}$ Exchanger } \\
\hline \multicolumn{4}{|l|}{$\mathrm{KCNG} 2 / 3$} \\
\hline \multicolumn{4}{|l|}{$\mathrm{Rh}$ antigen } \\
\hline \multicolumn{4}{|l|}{ IP3 receptor } \\
\hline \multicolumn{4}{|l|}{ Ryanodine receptor } \\
\hline \multicolumn{4}{|l|}{ Cell adhesion molecules: } \\
\hline \multicolumn{4}{|l|}{ L1-CAMs } \\
\hline \multicolumn{4}{|l|}{ CD44 } \\
\hline \multicolumn{4}{|l|}{ E-cadherin } \\
\hline \multicolumn{4}{|l|}{ Dystroglycan } \\
\hline \multicolumn{4}{|l|}{ Cellular transport: } \\
\hline \multicolumn{4}{|l|}{ Tubulin } \\
\hline Clathrin & & & \\
\hline
\end{tabular}

(Bennett and Healy 2008). The ankyrinbinding sites of $\beta$ spectrins $1-4$ are located in the 15th spectrin repeat, which is folded identically to other repeats but has distinct surfaceexposed residues (Davis et al. 2008; Ipsaro et al. 2009; Stabach et al. 2009) (Figs. 1A, 2A). Mammalian $\beta-5$ spectrin and its ortholog $\beta-\mathrm{H}$ spectrin in Drosophila and Caenorhabditis elegans are the only $\beta$ spectrins lacking ankyrinbinding activity (Dubreuil et al. 1990; Thomas et al. 1998; McKeown et al. 1998; Stabach and Morrow 2000).

Ankyrin interacts with $\beta$ spectrins through a ZU5 domain (Mohler et al. 2004a; Kizhatil et al. 2007a; Ipsaro et al. 2009) (Fig. 1B), and with most of its membrane partners through ANK repeats (Bennett and Baines 2001) (Fig. 2C,D). In addition, ankyrins have a highly conserve "death domain" and a carboxyterminal regulatory domain (see the following discussion). The 24 ANK repeats are stacked in a superhelical array to form a solenoid (Michaely et al. 2002). Interestingly, the ANK repeat stack behaves like a reversible spring when stretched by atomic force microscopy, and may function in mechano-coupling in tissues such as the heart (Lee et al. 2006). ANK repeats are components of many proteins and participate in highly diverse protein interactions (Mosavi et al. 2004) (Fig. 2C). 
V. Bennett and J. Healy

A

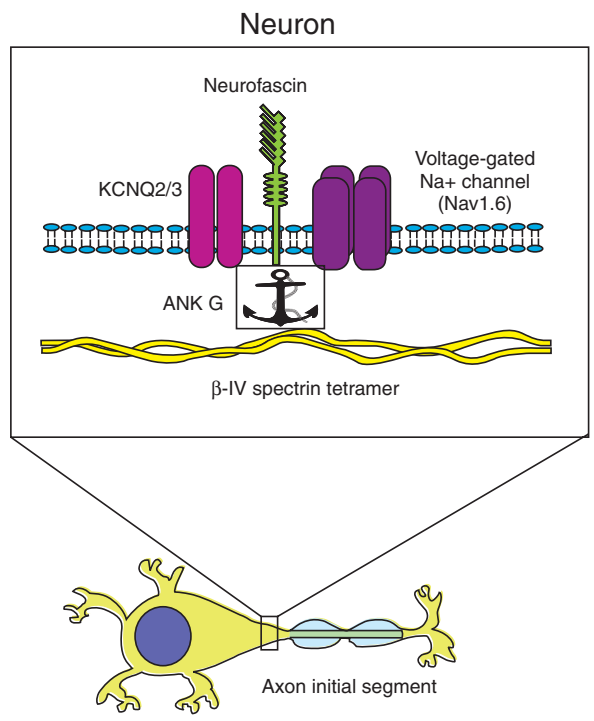

C

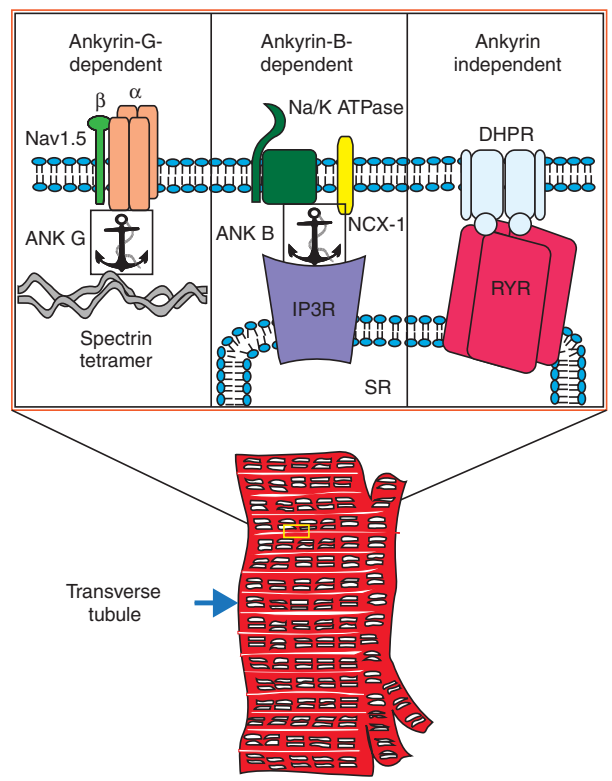

B

Skeletal muscle

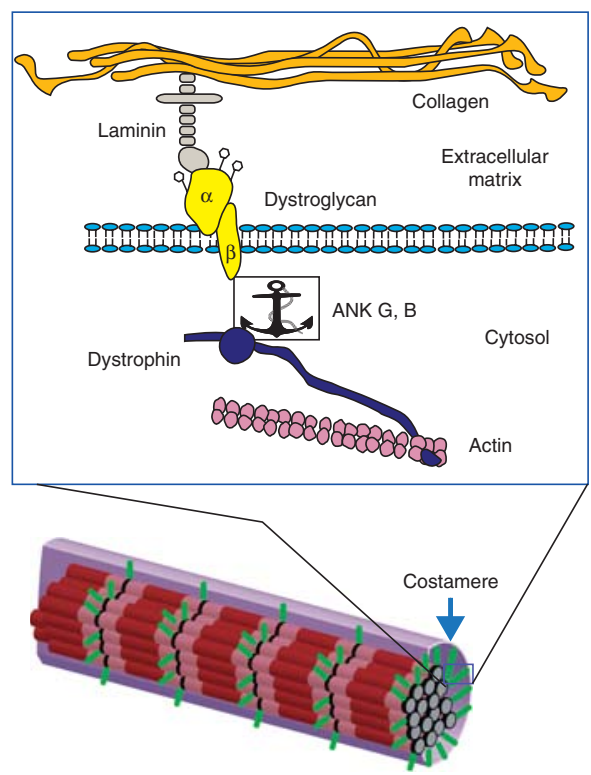

D

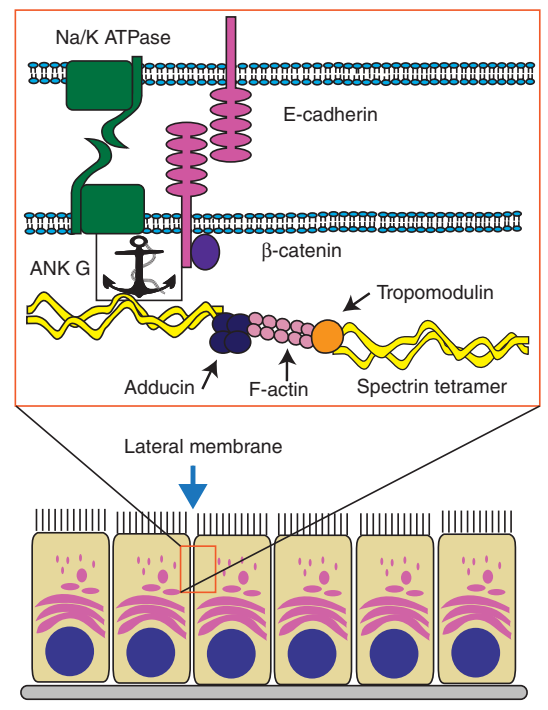

Figure 2. Ankyrins and spectrins organize macromolecular complexes in diverse types of specialized membranes. (A) Ankyrin-G forms a complex with $\beta$-IV spectrin, neurofascin (a cell adhesion protein), and ion channels (KCNQ2/3 and voltage-gated sodium channel) at axon initial segments in Purkinje neurons. (B) In force buffering costameres of skeletal muscle, ankyrins $-\mathrm{B}$ and $-\mathrm{G}$ cooperate to target and stabilize key components of the dystroglycoprotein complex. At the membrane, ankyrin-G binds to dystrophin and $\beta$-dystroglycan. $(C)$ In cardiomyocyte transverse tubules, ankyrins $-\mathrm{B}$ and $-\mathrm{G}$ coordinate separate microdomains. Ankyrin- $\mathrm{B}$ binds $\mathrm{Na}+/ \mathrm{K}+$ ATPase, $\mathrm{Na}+/ \mathrm{Ca}^{2+}$ exchanger (NCX-1), and the inositol triphosphate receptor (IP3R). Ankyrin-G forms a complex with Nav1.5 and spectrin. (D) Ankyrin-G in epithelial lateral membrane assembly. Ankyrin-G binds to E-cadherin, $\beta-2$ spectrin, and the $\mathrm{Na}+/ \mathrm{K}+$ ATPase. Spectrins are connected via $\mathrm{F}$-actin bridges bound to $\alpha / \gamma$ adducin and tropomodulin. 
This versatile motif currently is being exploited using designed ANK repeat proteins (DARPins) engineered to interact with specific ligands that can function as substitutes for antibodies (Stumpp and Amstutz 2007; Steiner et al. 2008).

Spectrin and ankyrin family members are expressed in most, if not all, animal (metazoan) cells, but are not present in bacteria, plants, or fungi. Spectrins are believed to have evolved from an ancestral $\alpha$-actinin containing calponin homology domains and two spectrin repeats but not other domains (Thomas et al. 1997; Pascual et al. 1997). Ankyrin repeats are expressed in all phyla, presumably because of a combination of evolutionary relationships and in cases of bacteria and viruses by horizontal gene transfer. However, the spectrin-binding domain of ankyrin is present only in metazoans (Fig 1B). It is possible that evolution of ankyrins and spectrins could have been one of the adaptations required for organization of cells into tissues in multicellular animals.

The human spectrin family includes two $\alpha$ subunits and five $\beta$ subunits, whereas Drosophila and $C$. elegans have a single $\alpha$ subunit and two $\beta$ subunits (Bennett and Baines 2001). Vertebrate ankyrins are encoded by three genes: ankyrin-R (ANK1) (the isoform first characterized in erythrocytes and also present in a restricted distribution in brain and muscle), ankyrin-B (ANK2), and ankyrin-G (ANK3). Vertebrate ankyrins evolved from a single gene in early chordates (Cai and Zhang 2006). C. elegans ankyrin is encoded by a single gene termed unc-44 (Otsuka et al. 1995), whereas the Drosophila genome contains two ankyrin genes: ankyrin (Dubreuil and Yu 1994) and ankyrin2 (Bouley et al. 2000).

Mammalian ankyrins -B and - $G$ are coexpressed in most cells, although they have distinct functions (Mohler et al. 2002; Abdi et al. 2006). Ankyrins -B and $-G$ are closely related in their ANK repeats, and spectrin-binding domains, but diverge in their carboxy-terminal regulatory domains. Regulatory domains are natively unstructured and extended (Abdi et al. 2006). These flexible domains engage in intramolecular interactions with the membranebinding and spectrin-binding domains (Hall and Bennett 1987; Davis et al. 1992; Abdi et al. 2006) that modulate protein associations and provide functional diversity between otherwise conserved ankyrins.

In addition to the standard versions of ankyrins and spectrin subunits depicted in Figure 1, many variants of these proteins are expressed with the addition and/or deletion of functional domains because of alternative splicing of pre-mRNAs. For example, $\beta$ spectrins can lack PH domains (Hayes et al. 2000), and giant ankyrins have insertions of up to 2000 residues (Kordeli et al. 1995; Chan et al. 1993; Pielage et al. 2008; Koch et al. 2008), whereas other ankyrins lack either the entire membrane-binding domain (Hoock et al. 1997), or both membrane- and spectrinbinding domains (Zhou et al. 1997). The insertions in $440 \mathrm{kDa}$ ankyrin- $\mathrm{B}$ and $480 \mathrm{kDa}$ ankyrin-G (Fig. 1B) have an extended conformation that potentially could have specialized roles in connections between the plasma membrane and cytoskeleton of axons where these giant ankyrins reside (Chan et al. 1993; Kordeli et al. 1995) (Fig. 1B). Interestingly, the inserted sequences in Drosophila giant ankyrins interact with microtubules at the presynaptic neuromuscular junction (Pielage et al. 2008) (see the following section).

\section{MEMBRANE-SPANNING PROTEIN PARTNERS}

Diverse families of membrane-spanning proteins, including ion channels, pumps, and exchangers as well as cell adhesion molecules have independently acquired ankyrin-binding activity multiple times in metazoan evolution (Table 1). These proteins include the anion exchanger (AE1) (Bennett and Stenbuck 1979b; Stefanovic et al. 2007), voltage-gated sodium channels (Srinivasan et al. 1988; Garrido et al. 2003; Lemaillet et al. 2003), $\mathrm{Na} / \mathrm{K}$ ATPase (Nelson and Veshnock 1987), $\mathrm{Na} / \mathrm{Ca}$ exchanger ( $\mathrm{Li}$ et al. 1993; Mohler et al. 2005; Cunha et al. 2007), IP3 receptors (Mohler et al. 2003; Mohler et al. 2005; Kline et al. 2008), $\mathrm{Rh}$ ammonium transporter (Nicolas et al. 2003; Lopez et al. 2005; Sohet 
et al. 2008), KCNQ2/3 channels (Pan et al. 2006; Chung et al. 2006; Rasmussen et al. 2007), Kv3.1 channels (Devaux et al. 2003; $\mathrm{Xu}$ et al. 2007), and cell adhesion molecules including L1 CAMs (Davis and Bennett 1994; Zhang et al. 1998), CD44 (Bourguignon et al. 1992), E- and N-cadherin (Kizhatil et al. 2007a), and $\beta$-dystroglycan (Ayalon et al. 2008) (Table 1). The ankyrin-binding sites have been defined in many of these proteins as relatively short stretches of 10-20 amino acids that do not contain a single defining motif (Fig. 3A). However, once ankyrin-binding activity appears in a protein family, the binding sites remain highly conserved. For example, the ankyrin-binding sites of human L1CAMs are nearly identical to the binding site of the L1 homolog of C. elegans (Chen et al. 2001), whereas sites of voltage-gated sodium channels and KCNQ2/3 channels are absent in Drosophila and but are conserved between humans and zebra fish (Pan et al. 2006).

Some membrane proteins such as NMDA receptors (Wechsler and Teichberg 1998), the neuronal glutamate transporter EAAT4 (Jackson et al. 2001), and the epithelial sodium channel (EnaC) (Rotin et al. 1994; Zuckerman et al. 1999) can associate directly with spectrin independently of ankyrin. Spectrin has also been reported to coimmunoprecipitate with the presynaptic voltage-sensitive calcium channel (Sunderland et al. 2000), although a direct interaction between these proteins has not been shown. Together, ankyrins and spectrins display a remarkable capacity for interactions with physiologically important membrane proteins.

\section{AXON INITIAL SEGMENTS AND NODES OF RANVIER}

Axon initial segments (Fig. 2A) and nodes of Ranvier are highly enriched in $480 / 270 \mathrm{kDa}$ alternatively spliced variants of ankyrin-G (Kordeli et al. 1995), $\beta-4$ spectrin (Berghs et al. 2000; Lacas-Gervais et al. 2004), as well as ankyrin-binding proteins including voltagegated $\mathrm{Na}$ channels and $186 \mathrm{kDa}$ neurofascin (Davis et al. 1996). Axon initial segments are of special importance as the integrator sites of neurons in which inputs from dendritic synapses (sometimes on the order of several hundred thousand) are transduced into action potentials. These action potentials result in both signaling to other neurons or target cells when propagated down the axon, and to modulation of synaptic function when backpropagated into dendritic shafts (Waters et al. 2005). In myelinated axons, action potentials are propagated at periodic interruptions in the myelin sheathe known as nodes of Ranvier.
A

\begin{tabular}{|ll|}
\hline \multicolumn{1}{|c|}{} & Ankyrin Binding Site \\
\hline NaV & VPIAGESDFE \\
\hline KCNQ2 & PYIAEGESDTDSD \\
\hline E-cadherin & $\begin{array}{l}\text { KEPLLPPEDDTRDNVYY- } \\
\text { YDEEGGGEED }\end{array}$ \\
\hline $\begin{array}{l}\text { Neurofascin/ } \\
\text { L1CAMs }\end{array}$ & QFNEDGSFIGQY \\
\hline RhBG & KLPFLDSPP \\
\hline Dystroglycan & GVPIIFADELDDSK \\
\hline AE1 & PAVLTRSGDPS \\
\hline
\end{tabular}

B

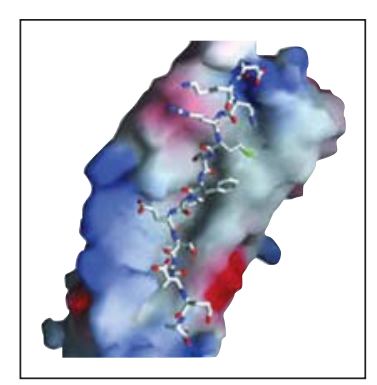

Figure 3. Ankyrins bind to natively unstructured regions of many proteins. (A) Known binding sites of ankyrin proteins. All of these regions lie in regions predicted to be intrinsically unstructured (http://iupred.enzim.hu/ IUPs.html). Abbreviations: NaV, voltage-gated sodium channels; KCNQ2, voltage-gated potassium channels; RhBG, rhesus blood group antigen; AE1, anion exchanger. (B) A theoretical model of how the ankyrin membrane binding domain could bind to unstructured peptides. This pocket is 240 angstroms in length with a variety of surface exposed residues. 
Myelin and nodes of Ranvier are adaptations of vertebrates that allow rapid nerve conduction using small caliber axons.

Targeted knockout of ankyrin-G in the postnatal cerebellum in mice results in severe ataxia, and loss of ability to fire action potentials as well as clustering of voltage-gated $\mathrm{Na}$ channels (Nav1.6) at axon initial segments of Purkinje neurons (Zhou et al. 1998; Jenkins and Bennett 2001). In addition, $\beta-4$ spectrin is absent and neurofascin is no longer restricted to ankyrinG-deficient initial segments (Jenkins and Bennett 2001). These result in Purkinje neurons that have been recapitulated in cultured hippocampal neurons, where knockdown of ankyrin-G results in mis-localization of $\beta-4$ spectrin, voltage-gated sodium channels, as well as neurofascin (Yang et al. 2007; Hedstrom et al. 2007).

$\beta-4$ spectrin knockout mice show diminution of the membrane undercoat and increased membrane blebbing at nodes of Ranvier (LacasGervais et al. 2004). Ankyrin-G recruits $\beta-4$ spectrin to nodes and initial segments (Jenkins and Bennett 2001; Yang et al. 2007), and is still present in the absence of $\beta-4$ spectrin. $\beta-4$ spectrin thus plays an important role in stabilizing these excitable membranes, following establishment by ankyrin-G alone at initial segments or by ankyrin-G in collaboration with axonal neurofascin and Schwann cell gliomedin at nodes of Ranvier (Eshed et al. 2005; Dzhashiashvili et al. 2007).

KCNQ2/3(Kv7) channels modulate activity of voltage-gated $\mathrm{Na}$ channels, and mutations in these channels results in hyperexcitability phenotypes including epilepsy (Maljevic et al. 2008; Neubauer et al. 2008). KCNQ2/3 channels colocalize with voltage-gated $\mathrm{Na}$ channels at nodes of Ranvier and axon initial segments (Devaux et al. 2004; Pan et al. 2006; Rasmussen et al. 2007). KCNQ2/3 channels have ankyrin-binding sites in their cytoplasmic domains, and require ankyrin-G for targeting to axon initial segments (Pan et al. 2006; Chung et al. 2006; Rasmussen et al. 2007).

Strikingly, knockdown of ankyrin-G in cultured hippocampal neurons results in loss of voltage-gated $\mathrm{Na}$ channels from initial segments and conversion of these domains into dendrites (Hedstrom et al. 2008). Ankyrin-G thus is required for preservation of the entire axon initial segment. It will be of interest to determine the role of ankyrin-G in the establishment of initial segments as well as whether ankyrin-G operates downstream of axonal polarity pathways.

Axon initial segments receive direct input through axo-axonic synapses of interneurons, which modulate neuronal output and may have roles in diseases such as epilepsy and schizophrenia (Howard et al. 2005). Loss of the neurofascin enrichment at the initial segment in ankyrin-G-deficient Purkinje neurons results in disruption of a class of synapses formed by interneurons that interconnect Purkinje neurons in the cerebellum (Ango et al. 2004). Ankyrin-G thus is responsible for stabilizing transcellular connections as well as organizing the composition of initial segments.

Spectrin and ankyrin are likely to function in other axonal domains. For example, paranodes are specialized zones immediately adjacent to the nodal gap in myelinated axons that contain shaker-type potassium channels and are characterized ultrastructurally by prominent axo-glial junctions. Paranodes contain a membrane skeleton distinct from nodes that includes $\beta-2$ spectrin, ankyrin- $B$, and protein 4.1 B (Ogawa et al. 2006). $\alpha-2$ Spectrin is present in paranodes where it associates with $\beta-2$ spectrin, and also at the nodal gap where it partners with $\beta-4$ spectrin. $\alpha-2$ Spectrin mutations in zebra fish result in abnormal development of nodes of Ranvier, and are responsible for stabilizing initial clusters of voltage-gated Na channels (Voas et al. 2007).

Ankyrin-binding activity of its membrane partners is not "hardwired," but is subject to regulation. Phosphorylation of neurofascin at the FIGQY tyrosine in its ankyrin-binding site abolishes ankyrin-binding (Garver et al. 1997; Whittard et al. 2006) and results in gain of function in binding to doublecortin (Kizhatil et al. 2002). FIGQY-phosphorylated neurofascin is excluded from the node of Ranvier but is concentrated in paranodes (Jenkins et al. 2001). Ankyrin-binding activity of the 
voltage-gated sodium channel is markedly enhanced by phosphorylation by casein kinase 2 (Bréchet et al. 2008). Interestingly, casein kinase 2 is concentrated at nodes of Ranvier and axon initial segments, and could provide a local activation signal for stabilizing voltagegated sodium channels at these sites (Bréchet et al. 2008).

\section{NEUROMUSCULAR JUNCTIONS}

Spectrin and ankyrin stabilize neuromuscular junctions through both presynaptic and postsynaptic mechanisms. Presynaptic $\beta$ spectrin is required for normal transmitter release and to stabilize Drosophila neuromuscular junctions following initial establishment of these synapses (Featherstone et al. 2001; Pielage et al. 2005). Interestingly, two groups independently identified presynaptic giant ankyrin-2 isoforms through different unbiased forward genetic screens for mutations affecting the Drosophila neuromuscular junction (Koch et al. 2008; Pielage et al. 2008). The phenotypes of ankyrinmutant junctions included retraction of synaptic boutons, loss of axonal microtubules, and misorganization of synaptic cell adhesion molecules. The defects in synaptic stability increased with distance from the neuron cell body and were accompanied by accumulation of synaptic vesicles in axons, suggesting a role of ankyrins in axonal transport in addition to their local function at the synapse (Koch et al. 2008).

Spectrin and ankyrin-G are localized in specialized postsynaptic domains in mammalian neuromuscular junctions that are distinct from the acetylcholine receptor and are enriched in voltage-gated sodium channels (Flucher and Daniels 1989; Wood and Slater 1998; Kordeli et al. 1998; Bailey et al. 2003). Ankyrin-B also is located at the periphery of mammalian neuromuscular junctions (Ayalon et al. 2008). Experiments in flies and mice show that postsynaptic spectrin and ankyrins are required to stabilize neuromuscular junctions. Knockdown of postsynaptic spectrin in the Drosophila by siRNA results in misorganization of active zones and abnormal growth of the neuromuscular junction (Pielage et al. 2006). Similarly, knockdown of postsynaptic ankyrin-B in adult mouse muscle results in shrinkage of the neuromuscular junction from its adult form back to the size of neonatal junctions (Ayalon et al. 2008).

\section{COSTAMERES}

Costameres (Fig. 2B) are specialized domains formed at the junction of the plasma membrane and Z-discs of peripheral myofibrils in skeletal muscle and cardiomyocytes (Pardo et al. 1983; Rybakova et al. 2000; Ervasti 2003; Bloch et al. 2004). Costameres function as force buffers that transmit force across the plasma membrane from sarcomeres to the extracellular matrix, and protect the muscle plasma membrane from damage during contraction. The dystrophin-glycoprotein complex (DGC) provides a transmembrane connection at costameres through association of dystrophin with $\gamma$-actin and dystroglycan, and dystroglycan with extracellular laminin (Ervasti, 2003; Rybakova et al. 2000). The dystrophinglycoprotein-complex is absent from the plasma membrane in Duchenne muscular dystrophy, which results in membrane damage and contributes to death of muscle cells (Ervasti et al. 1990; Cohn and Campbell 2000; Dalkilic and Kunkel 2003).

Ankyrin-B and ankyrin-G cooperate in localization of dystrophin and $\beta$-dystroglycan at costameres and are required to prevent exercise-induced injury (Ayalon et al. 2008). Ankyrin-B is required for transport of $\beta$ dystroglycan to the plasma membrane, whereas ankyrin-G retains $\beta$-dystroglycan at costameres. Loss of ankyrin-B in skeletal muscle is accompanied by loss of microtubules, both at the neuromuscular junction (see previous discussion) as well as costameres (Ayalon et al. 2008). Ankyrin-B binds directly to dynactin-4/p62 of the dynactin complex, and may capture fast-growing ends of microtubules at costameres and neuromuscular junctions to establish transport routes from the trans-Golgi network for newly synthesized $\beta$-dystroglycan (Ayalon et al. 2008). 


\section{CARDIOMYOCYTE T-TUBULE MICRODOMAINS}

Rhythmic contraction of mammalian hearts requires nearly synchronous waves of calcium release and reuptake throughout the intracellular space of ventricular cardiomyocytes. This is achieved though precise placement of membrane transporters and signaling molecules related to import and export of calcium within microdomains of T-tubules (Fig. 2C). T-tubules are invaginations of the plasma membranes that form a complex three-dimensional network juxtaposed to the sarcoplasmic reticulum (Brette and Orchard 2007). Ventricular myocyte T-tubules contain three microdomains that can be resolved by high resolution light microscopy: A domain containing L-type voltage-gated calcium channels complexed with ryanodine receptors in the sarcoplasmic reticulum, a second domain enriched in the $\mathrm{Na} / \mathrm{Ca}$ exchanger, and a third domain enriched in voltage-gated sodium channels (Scriven et al. 2000). Voltage-gated sodium channels are responsible for activating voltage-gated calcium channels, which admit a small amount of calcium and activate calcium release from the sarcoplasmic reticulum. The $\mathrm{Na} / \mathrm{Ca}$ exchanger contributes to calcium homeostasis by export of calcium back across the T-tubule. Evidence will be reviewed below indicating that ankyrin$\mathrm{B}$ is required for the $\mathrm{Na} / \mathrm{Ca}$ exchanger microdomain, and ankyrin- $\mathrm{G}$ is required for the domain enriched in voltage-gated sodium channels.

The $\mathrm{Na} / \mathrm{Ca}$ exhanger (NCX1) binds to ankyrin-B and colocalizes with ankyrin-B in cardiomyocyte T-tubules (Li et al. 1993; Mohler et al. 2005; Cunha et al. 2007). In addition, NCX1 and ankyrin-B also colocalize with the $\mathrm{Na} / \mathrm{K}$ ATPase in the T-tubule membrane and with the IP3 receptor in the sarcoplasmic reticulum (Mohler et al. 2005). Haploinsufficiency of ankyrin-B in mice results in selective loss of T-tubule-localized sodium/calcium exchanger, $\mathrm{Na} / \mathrm{K}$ ATPase as well as IP3 receptor from adult cardiomyocytes (Mohler et al. 2003; 2005). Moreover, ankyrin-B-deficient cardiomyocytes show increased contractility and increased calcium transients (Mohler et al. 2003; 2005).
These observations suggest that ankyrin-Bdependent colocalization of NCX1 and $\mathrm{Na} / \mathrm{K}$ ATPase could result in functional coupling between these transporters, with $\mathrm{Na} / \mathrm{K}$ ATPasedriven export of sodium ions entering the cell in exchange for calcium ions. The IP3 receptor in the ankyrin-B complex has been proposed to function in coupled calcium export from the sarcoplasmic reticulum directly through NCX1 (Mohler et al. 2005). The physiological importance of the ankyrin-B-microdomain in T-tubules is supported by findings that ankyrin-B-deficient mice and humans heterozygous for loss-of-function mutations of ankyrin-B show stress-induced sudden cardiac death and cardiac arrhythmia symptoms (Mohler et al. 2003; 2004b).

Nav1.5 and ankyrin-G and are both localized to T-tubules and intercalated discs of adult cardiomyoctes (Mohler et al. 2004c). Although high-resolution double-labeling for these proteins has not been reported, several findings strongly indicate that Nav1.5 and ankyrin-G are molecular partners in the heart. E1053K mutation of the ankyrin-binding site of Nav1.5 eliminates ankyrin-G-binding as well as ability of Nav1.5 to accumulate at the cell surface of cardiomyocytes (Mohler et al. 2004c). Interestingly, this Nav1.5 mutation is associated with Brugada syndrome, which is a cardiac arrhythmia associated with lossof-function mutations of Nav1.5. Nav1.5 requires interaction with ankyrin- $G$ through ank repeats 14 and 15 for expression at the cell surface of neonatal cardiomyocytes (Lowe et al. 2008).

\section{EPITHELIAL LATERAL MEMBRANES}

The lateral membrane domain of epithelial cells (Fig. 2D) is of considerable physiological importance because of its roles in salt and water homeostasis and protection of epithelial tissues from mechanical stress. Moreover, loss of this specialized domain is a hallmark of metastatic cancer cells. Early immunofluorescence studies identified ankyrin and spectrin in a polarized pattern localized to lateral membranes of cultured epithelial cells as well as in 
tissues (Drenckhahn et al. 1985; Nelson and Veshnock 1986; Drenckhahn and Bennett 1987). More recently, studies using siRNA have revealed that ankyrin-G and $\beta-2$ spectrin collaborate in formation of the lateral membrane of bronchial epithelial cells (Kizhatil and Bennett 2004; Kizhatil et al. 2007b). Cells depleted of either protein maintain apicalbasal polarity, but fail to form new lateral membrane following initiation of cell-cell contact and remain flattened rather than columnar. Moreover, ankyrin-G and $\beta-2$ spectrin-depleted cells are incapable of de novo membrane biogenesis during mitosis (Kizhatil et al. 2007b). Ankyrin-G requires $\beta-2$ spectrin as a partner because ankyrin-G mutants lacking $\beta-2$ spectrin-binding activity are not active in restoring the lateral membrane (Kizhatil et al. 2007b). Ankyrin-G and $\beta$-2 spectrin thus work together in bulk delivery of proteins and phospholipids to the lateral membrane.

$\beta$ spectrins associated with intracellular membranes were initially believed to be distinct from those associated with the plasma membrane. Beck and colleagues reported spectrin immunoreactivity associated with the Golgi (Beck et al. 1994), which was later attributed to $\beta-3$ spectrin (Stankewich et al. 1998). However, the cross-reacting protein in Golgi was subsequently determined to be syne-1 (also termed nesprin), which has spectrinrepeats but is otherwise distantly related to $\beta$ spectrins (Gough et al. 2003). $\beta-3$ spectrin is very similar to $\beta-2$ spectrin, but has a more restricted pattern of expression primarily in the nervous system and especially the cerebellum (Sakaguchi et al. 1998). $\beta$-3 spectrin thus may have roles in intracellular transport similar to $\beta-2$ spectrin but is not a specialized component of the Golgi apparatus. Recently, mutations in $\beta-3$ spectrin were identified as the cause of a form of spinocerebellar ataxia (SCA5) (Ikeda et al. 2006), indicating an important role in maintenance of certain neurons.

E-cadherin is a key cell adhesion molecule that is required to form the first lateral membrane domains in development and is a ubiquitous component of lateral membranes in epithelial tissues. E-cadherin has recently been reported to bind to ankyrin-G through a highly conserved site in its cytoplasmic domain and to require ankyrin-binding activity for efficient exit from the trans Golgi network (Kizhatil et al. 2007a). Moreover, both ankyrin-G and $\beta-2$ spectrin are required for accumulation of E-cadherin at the lateral membrane in both epithelial cells and preimplantation embryos. E-cadherin thus works together with ankyrin- $G$ and $\beta-2$ spectrin to coordinate membrane assembly with extracellular interactions of at sites of cell-cell contact. Coupling of E-cadherin to a versatile adaptor protein such as ankyrin-G could promote corecruitment of diverse proteins to sites of cell-cell contact. For example, ankyrin-G associates with other lateral membrane proteins including the $\mathrm{Na} / \mathrm{K}$ ATPase (Nelson and Veshnock, 1987) and the RhBG ammonium transporter (Lopez et al. 2005). It will be important to determine if ankyrinbinding activity is shared by other proteins residing in the lateral membrane.

Spectrin-actin complexes are stabilized by accessory proteins such as adducin, which recruits spectrin to the fast-growing end of actin filaments (Gardner and Bennett 1987; Li et al. 1998; Kuhlman et al, 1996), and tropomodulin, which caps the slow-growing ends of actin filaments (Littlefield and Fowler 2008). Adducin and tropomodulin are both required to stabilize spectrin-actin networks on the lateral membrane of epithelial cells (Abdi and Bennett 2008; Weber et al. 2007). Depletion of either protein by siRNA results in loss of lateral membrane height. Moreover, depletion of adducin increases long-range mobility of E-cadherin on the lateral membrane (Abdi and Bennett 2008). Adducin is phosphorylated and inactivated by protein kinase C (Matsuoka et al. 1998), suggesting the possibility of signals that modulate the stability of the spectrinactin network in the lateral membrane. Interestingly in this regard, pleiotrophin is a cytokine that promotes adducin phosphorylation and increased proliferation of epithelial cells (Pariser et al. 2005). 


\section{CORE MECHANISMS AND EVOLUTION OF MEMBRANE DOMAINS}

Having gone into details of individual membrane domains, it is worthwhile to consider common requirements and the special features of ankyrins and spectrins that satisfy these core needs. All of the domains considered in this review depend on corecruitment of functionally related but structurally distinct membrane partners. For example, axon initial segments are enriched in voltage-gated $\mathrm{Na}$ channels, KCNQ2/3 channels, and $186 \mathrm{kDa}$ neurofascin (Fig. 2A), lateral membranes have E-cadherin and the $\mathrm{Na} / \mathrm{K}$ ATPase (Fig. 2D), and ankyrin-B-based cardiomyocyte T-tubule domains contain the $\mathrm{Na} / \mathrm{K}$ ATPase together with the Na/Ca exchanger (Fig. 2C). These proteins all have independently evolved ability to bind to ankyrin. A shared feature of many ankyrin-binding sites is that they are either predicted or shown to be extended peptides lacking secondary structure. For example the anion exchanger site is an 11 amino-acid loop based on the crystal structure (Stefanovic et al. 2007), the cytoplasmic domains of E-cadherin and L1 CAMS are established to be natively unstructured by biophysical methods (Huber et al. 2001; Zhang et al. 1998), and sites of Nav channels, KCNQ2/3 channels, RhBG ammonium transporter, and $\beta$-dystroglycan are predicted to be unstructured (Fig. 3A).

A possible binding site for unstructured peptides could be the ankyrin groove that runs the 240-angstrom length of the repeat stack (Michaely et al. 2002) (Fig. 3A,B). A groove of this length with variation in surface-exposed residues could potentially accommodate multiple types of partners. Interestingly, ANK repeats can bind to more than one partner at a time and thus are capable of forming homoand hetero-complexes (Michaely and Bennett, 1995).

Natively unstructured domains of proteins are widely used in protein recognition (Dyson and Wright 2005). One advantage of such a code is that unstructured proteins can multitask and also engage endocytic machinery and other adaptor proteins depending on cellular requirements. Another advantage is that the affinity for ankyrin can vary: The $\mathrm{Kd}$ for ankyrin is $10 \mathrm{nM}$ for the anion exchanger, $50 \mathrm{nM}$ for neurofascin, and $500 \mathrm{nM}$ for E-cadherin. This variable affinity allows for flexibility depending on the physiological context. Finally, intrinsically unstructured proteins represent the most rapidly evolving part of the genome (Brown et al. 2002), and have the potential to adjust readily to new physiological demands such as the rapid acquisition of myelination.

Another emerging theme as we learn more about ankyrin-based membrane domains is that they assemble through direct targeting of components along microtubules to specific sites. A similar direct targeting pathway has been proposed for assembly of gap junction subunits at adherens junctions (Shaw et al. 2007). Direct targeting is in contrast to many current models that invoke endocytosis and transcytosis as primary mechanisms for sorting. Ankyrins can bind directly to microtubules (Bennett and Davis 1981), and also can serve as adaptors for the dynactin complex, which can stabilize the fast-growing ends of microtubules, at least in skeletal muscle (Ayalon et al. 2008). Ankyrins also stabilize microtubules at the presynaptic neuromuscular junction, and also may have roles in axonal transport (Pielage et al. 2008; Koch et al. 2008). A current mystery is how newly synthesized membrane proteins are coupled to the appropriate microtubules, especially in epithelial cells and neurons where multiple types of microtubules coexist.

In addition to their roles in stabilizing proteins at the plasma membrane and in directed transport, ankyrin and spectrin may also establish specialized membrane domains. For example, ankyrin-G and $\beta-2$ spectrin are required for biogenesis of epithelial lateral membranes (Kizhatil and Bennett 2004; Kizhatil et al, 2007b). Ankyrin-G also is required to form axon initial segments, which lose all initial segment markers and develop dendritic properties in ankyrin-G-knockdown cells (Hedstrom et al. 2008). Clues to how ankyrins and $\beta$ spectrins could participate in 
bulk transport of proteins and phospholipids in assembly of membrane domains come from the findings that $\beta-2$ spectrin interacts with membrane phospholipids through multiple sites (An et al. 2004; Muresan et al. 2001), and with PI lipids through its $\mathrm{PH}$ domain (Hyvönen et al. 1995). Moreover, spectrins also interact with microtubule-based motors, either directly (Takeda et al. 2000), or through dynactin (Muresan et al. 2001; Holleran et al. 2001; Holleran et al. 1996). The combination of ankyrin, with its diversity in protein recognition, and $\beta$ spectrin, with its capacity to connect membrane compartments with microtubule-based motors, seems well suited for segregation and transport of membrane proteins and lipids to specialized domains. A central unanswered question is the identity of the initial polarity signals that define the site of delivery for ankyrin/spectrin cargo.

\section{SUMMARY AND PERSPECTIVES}

Ankyrins and spectrins were first discovered as partners in plasma membrane of erythrocytes, but now are established to be required for specialized membrane domains in many types of cells. Spectrins can both form a twodimensional actin-based network on the plasma membrane that restricts membranespanning proteins, as well as participate in microtubule-dependent transport of membrane lipids and proteins. Ankyrins serve as membrane adaptors that connect spectrin to diverse membrane-spanning proteins through recognition by ANK repeats. Currently characterized ankyrin-binding sites are short 10-20 amino acid stretches that do not have a single shared motif but are intrinsically unstructured or configured as a loop. Ankyrins, in many cases operating with spectrins, are involved in coordinate assembly of a variety of ion transporters and cell adhesion molecules at axon initial segments and nodes of Ranvier in myelinated nerves, the neuromuscular junction, T-tubule microdomains in cardiomyocytes, costameres in striated muscle, and the lateral membrane domain of epithelial cells. Cardiac arrhythmias result from mutation or deficiency of ankyrin-B or mutation of ankyrin-G-binding site of the cardiac voltage-gated sodium channel. It is likely that additional human diseases will turn out to result from defects in organization of membrane proteins. Important questions for future work include elucidation of the polarity signals that define where these domains are localized in cells as well as resolving their assembly mechanisms involving sorting and preferential transport. It is clear that future resolution of the core mechanisms for roles of ankyrins and spectrins in membrane domains will have pervasive implications for physiology as well as clinical medicine.

\section{ACKNOWLEDGMENTS}

JH was supported by a predoctoral fellowship from the American Heart Association. VB was supported in part by a grant from the Muscular Dystrophy Association.

\section{REFERENCES}

Abdi KM, Bennett V. 2008. Adducin promotes micrometer-scale organization of $\beta 2$-spectrin in lateral membranes of bronchial epithelial cells. Mol Biol Cell 19: 536-545.

Abdi KM, Mohler PJ, Davis JQ, Bennett V. 2006. Isoform specificity of ankyrin-B: A site in the divergent Cterminal domain is required for intramolecular association. J Biol Chem 281: 5741-5749.

An X, Guo X, Sum H, Morrow J, Gratzer W, Mohandas N. 2004. Phosphatidylserine binding sites in erythroid spectrin: Location and implications for membrane stability. Biochemistry 43: 310-315.

Ango F, di Cristo G, Higashiyama H, Bennett V, Wu P, Huang ZJ. 2004. Ankyrin-based subcellular gradient of neurofascin, an immunoglobulin family protein, directs GABAergic innervation at purkinje axon initial segment. Cell 119: 257-272.

Ayalon G, Davis JQ, Scotland PB, Bennett V. 2008. An ankyrin-based mechanism for functional organization of dystrophin and dystroglycan. Cell 135: 1189-1200.

Bailey SJ, Stocksley MA, Buckel A, Young C, Slater CR. 2003. Voltage-gated sodium channels and ankyrin-G occupy a different postsynaptic domain from acetylcholine receptors from an early stage of neuromuscular junction maturation in rats. J Neurosci 23: 2102-2111.

Bañuelos S, Saraste M, Djinović Carugo K. 1998. Structural comparisons of calponin homology domains: Implications for actin binding. Structure 6: 1419-1431.

Beck KA, Buchanan JA, Malhotra V, Nelson WJ. 1994. Golgi spectrin: Identification of an erythroid $\beta$-spectrin 
homolog associated with the Golgi complex. J Cell Biol 127: $707-723$

Bennett V. 1978. Purification of an active proteolytic fragment of the membrane attachment site for human erythrocyte spectrin. J Biol Chem 253: 2292-2299.

Bennett V, Baines AJ. 2001. Spectrin and ankyrin-based pathways: Metazoan inventions for integrating cells into tissues. Physiol Rev 81: 1353-1392.

Bennett V, Davis J. 1981. Erythrocyte ankyrin: Immunoreactive analogues are associated with mitotic structures in cultured cells and with microtubules in brain. Proc Natl Acad Sci 78: 7550-7554.

Bennett V, Healy J. 2008. Organizing the fluid membrane bilayer: Diseases linked to spectrin and ankyrin. Trends Mol Med 14: 28-36.

Bennett V, Stenbuck PJ. 1979a. Identification and partial purification of ankyrin, the high affinity membrane attachment site for human erythrocyte spectrin. J Biol Chem 254: 2533-2541.

Bennett V, Stenbuck PJ. 1979b. The membrane attachment protein for spectrin is associated with band 3 in human erythrocyte membranes. Nature 280: 468-473.

Bennett V, Davis JQ, Fowler WE. 1982. Brain spectrin, a membrane-associated protein related in structure and function to erythrocyte spectrin. Nature 299: 126-131.

Berghs S, Aggujaro D, Dirkx R Jr, Maksimova E, Stabach P, Hermel JM, Zhang JP, Philbrick W, Slepnev V, Ort T, et al. 2000. BIV spectrin, a new spectrin localized at axon initial segments and nodes of ranvier in the central and peripheral nervous system. J Cell Biol 151: 985-1002.

Bloch RJ, Reed P, O’Neill A, Strong J, Williams M, Porter N, Gonzalez-Serratos H. 2004. Costameres mediate force transduction in healthy skeletal muscle and are altered in muscular dystrophies. J Muscle Res Cell Motil 25: 590-592.

Bouley M, Tian MZ, Paisley K, Shen YC, Malhotra JD, Hortsch M. 2000. The L1-type cell adhesion molecule neuroglian influences the stability of neural ankyrin in the Drosophila embryo but not its axonal localization. J Neurosci 20: 4515-4523.

Bourguignon LY, Lokeshwar VB, He J, Chen X, Bourguignon GJ. 1992. A CD44-like endothelial cell transmembrane glycoprotein (GP116) interacts with extracellular matrix and ankyrin. Mol Cell Biol 12: 4464-4471.

Bréchet A, Fache MP, Brachet A, Ferracci G, Baude A, Irondelle M, Pereira S, Leterrier C, Dargent B. 2008. Protein kinase CK2 contributes to the organization of sodium channels in axonal membranes by regulating their interactions with ankyrin G. J Cell Biol 183: 1101-1114.

Brette F, Orchard C. 2007. Resurgence of cardiac t-tubule research. Physiology (Bethesda). 22: 167-173.

Brown CJ, Takayama S, Campen AM, Vise P, Marshall TW, Oldfield CJ, Williams CJ, Dunker AK. 2002. Evolutionary rate heterogeneity in proteins with long disordered regions. J Mol Evol 55: 104-110.

Byers TJ, Branton D. 1985. Visualization of the protein associations in the erythrocyte membrane skeleton. Proc Natl Acad Sci 82: 6153-6157.

Chen L, Ong B, Bennett V. 2001. LAD-1, the Caenorhabditis elegans L1CAM homologue, participates in embryonic and gonadal morphogenesis and is a substrate for fibroblast growth factor receptor pathway-dependent phosphotyrosine-based signaling. J Cell Biol 154: $841-855$.

Cai X, Zhang Y. 2006. Molecular evolution of the ankyrin gene family. Mol Biol Evol 23: 550-558.

Chan W, Kordeli E, Bennett V. 1993. 440-kD ankyrin-B: Structure of the major developmentally regulated domain and selective localization in unmyelinated axons. J Cell Biol 123: 1463-1473.

Chung HJ, Jan YN, Jan LY. 2006. Polarized axonal surface expression of neuronal KCNQ channels is mediated by multiple signals in the KCNQ2 and KCNQ3 C-terminal domains. Proc Natl Acad Sci 103: 8870-8875.

Clarke M. 1971. Isolation and characterization of a watersoluble protein from bovine erythrocyte membranes. Biochem Biophys Res Commun 45: 1063-1070.

Cohn RD, Campbell KP. 2000. Molecular basis of muscular dystrophies. Muscle Nerve 23: 1456-1471.

Cunha SR, Bhasin N, Mohler PJ. 2007. Targeting and stability of $\mathrm{Na} / \mathrm{Ca}$ exchanger 1 in cardiomyocytes requires direct interaction with the membrane adaptor ankyrin-B. J Biol Chem 282: 4875-4883.

Dalkilic I, Kunkel LM. 2003. Muscular dystrophies: genes to pathogenesis. Curr Opin Genet Dev 13: 231-238.

Davis J, Bennett V. 1983. Brain spectrin. Isolation of subunits and formation of hybrids with erythrocyte spectrin subunits. J Biol Chem 258: 7757-7766.

Davis JQ, Bennett V. 1994. Ankyrin binding activity shared by the neurofascin/L1/NrCAM family of nervous system cell adhesion molecules. J Biol Chem 269: 27163-27166.

Davis LH, Davis JQ, Bennett V. 1992. Ankyrin regulation: An alternatively spliced segment of the regulatory domain functions as an intramolecular modulator. $J$ Biol Chem 267: 18966-18972.

Davis JQ, Lambert S, Bennett V. 1996. Molecular composition of the node of Ranvier: Identification of ankyrinbinding cell adhesion molecules neurofascin (mucin+/ third FNIII domain-) and NrCAM at nodal axon segments. J Cell Biol 135: 1355-13567.

Davis L, Abdi K, Machius M, Brautigam C, Tomchick DR, Bennett V, Michaely P. 2008. Localization and structure of the ankyrin-binding site on $\beta 2$-spectrin. J Biol Chem 284: 6982-6987.

Devaux J, Alcaraz G, Grinspan J, Bennett V, Joho R, Crest M, Scherer SS. 2003. Kv3.1b is a novel component of CNS nodes. J Neurosci 23: 4509-4518.

Devaux JJ, Kleopa KA, Cooper EC, Scherer SS. 2004. KCNQ2 is a nodal $\mathrm{K}+$ channel. J Neurosci 24: 1236-1244.

Drenckhahn D, Bennett V. 1987. Polarized distribution of Mr 210,000 and 190,000 analogs of erythrocyte ankyrin along the plasma membrane of transporting epithelia, neurons and photoreceptors. Eur J Cell Biol 43: 479-486.

Drenckhahn D, Schlüter K, Allen DP, Bennett V. 1985. Colocalization of band 3 with ankyrin and spectrin at the basal membrane of intercalated cells in the rat kidney. Science 230: 1287-1289.

Dubreuil RR, Yu J. 1994. Ankyrin and $\beta$-spectrin accumulate independently of $\alpha$-spectrin in Drosophila. Proc Natl Acad Sci 91: 10285-10289. 
V. Bennett and J. Healy

Dubreuil RR, Byers TJ, Stewart CT, Kiehart DP. 1990. A $\beta$-spectrin isoform from Drosophila $(\beta \mathrm{H})$ is similar in size to vertebrate dystrophin. J Cell Biol 111: $1849-1858$.

Dyson HJ, Wright PE. 2005. Intrinsically unstructured proteins and their functions. Nat Rev Mol Cell Biol 6: 197-208.

Dzhashiashvili Y, Zhang Y, Galinska J, Lam I, Grumet M, Salzer JL. 2007. Nodes of Ranvier and axon initial segments are ankyrin G-dependent domains that assemble by distinct mechanisms. J Cell Biol 177: 857-870.

Ervasti JM. 2003. Costameres: The Achilles' heel of Herculean muscle. J Biol Chem 278: 13591-13594.

Ervasti JM, Ohlendieck K, Kahl SD, Gaver MG, Campbell KP. 1990. Deficiency of a glycoprotein component of the dystrophin complex in dystrophic muscle. Nature 345: 315-319.

Eshed Y, Feinberg K, Poliak S, Sabanay H, Sarig-Nadir O, Spiegel I, Bermingham JR Jr, Peles E. 2005. Gliomedin mediates Schwann cell-axon interaction and the molecular assembly of the nodes of Ranvier. Neuron 47: 215-229.

Featherstone DE, Davis WS, Dubreuil RR, Broadie K. 2001. Drosophila $\alpha$ - and $\beta$-spectrin mutations disrupt presynaptic neurotransmitter release. J Neurosci 21: 4215-4224.

Flucher BE, Daniels MP. 1989. Distribution of $\mathrm{Na}+$ channels and ankyrin in neuromuscular junctions is complementary to that of acetylcholine receptors and the 43 kd protein. Neuron 3:163-175.

Gardner K, Bennett V. 1987. Modulation of spectrin-actin assembly by erythrocyte adducin. Nature 328: $359-362$.

Garrido JJ, Giraud P, Carlier E, Fernandes F, Moussif A, Fache MP, Debanne D, Dargent B. 2003. A targeting motif involved in sodium channel clustering at the axonal initial segment. Science 300: 2091-2094.

Garver TD, Ren Q, Tuvia S, Bennett V. 1997. Tyrosine phosphorylation at a site highly conserved in the L1 family of cell adhesion molecules abolishes ankyrin binding and increases lateral mobility of neurofascin. J Cell Biol 137: 703-714.

Gough LL, Fan J, Chu S, Winnick S, Beck KA. 2003. Golgi localization of Syne-1. Mol Biol Cell 14: 2410-2424.

Hall TG, Bennett V. 1987. Regulatory domains of erythrocyte ankyrin. J Biol Chem 262: 10537-10545.

Hayes NV, Scott C, Heerkens E, Ohanian V, Maggs AM, Pinder JC, Kordeli E, Baines AJ. 2000. Identification of a novel C-terminal variant of $\beta$ II spectrin: Two isoforms of $\beta$ II spectrin have distinct intracellular locations and activities. J Cell Sci 113: 2023-2034.

Hedstrom KL, Ogawa Y, Rasband MN. 2008. Ankyrin-G is required for maintenance of the axon initial segment and neuronal polarity. J Cell Biol 183: 635-640.

Hedstrom KL, Xu X, Ogawa Y, Frischknecht R, Seidenbecher CI, Shrager P, Rasband MN. 2007. Neurofascin assembles a specialized extracellular matrix at the axon initial segment. J Cell Biol 178: 875-886.

Hoock TC, Peters LL, Lux SE. 1997. Isoforms of ankyrin-3 that lack the $\mathrm{NH} 2$-terminal repeats associate with mouse macrophage lysosomes. J Cell Biol 136: 1059-1070.
Howard A, Tamas G, Soltesz I. 2005. Lighting the chandelier: New vistas for axo-axonic cells. Trends Neurosci 28: $310-316$.

Ikeda Y, Dick KA, Weatherspoon MR, Gincel D, Armbrust KR, Dalton JC, Stevanin G, Dürr A, Zühlke C, Bürk K, et al. 2006. Spectrin mutations cause spinocerebellar ataxia type 5. Nat Genet 38: 184-190.

Ipsaro JJ, Huang L, Mondragon A. 2009. Structures of the spectrin-ankyrin interaction binding domains. Blood doi: 10.1182/blood-2008-10-184358.

Jackson M, Song W, Liu MY, Jin L, Dykes-Hoberg M, Lin CI, Bowers WJ, Federoff HJ, Sternweis PC, Rothstein JD. 2001. Modulation of the neuronal glutamate transporter EAAT4 by two interacting proteins. Nature 410: 89-93.

Jenkins SM, Bennett V. 2001. Ankyrin-G coordinates assembly of the spectrin-based membrane skeleton, voltagegated sodium channels, and L1 CAMs at Purkinje neuron initial segments. J Cell Biol 155: 739-746.

Jenkins SM, Kizhatil K, Kramarcy NR, Sen A, Sealock R, Bennett V. 2001. FIGQY phosphorylation defines discrete populations of L1 cell adhesion molecules at sites of cellcell contact and in migrating neurons. J Cell Sci 114: 3823-3835.

Holleran EA, Ligon LA, Tokito M, Stankewich MC, Morrow JS, Holzbaur EL. 2001. $\beta$ III spectrin binds to the Arp1 subunit of dynactin. J Biol Chem 276: 36598-36605.

Holleran EA, Tokito MK, Karki S, Holzbaur EL. 1996. Centractin (ARP1) associates with spectrin revealing a potential mechanism to link dynactin to intracellular organelles. J Cell Biol 135: 1815-1829.

Huber AH, Stewart DB, Laurents DV, Nelson WJ, Weis WI. 2001. The cadherin cytoplasmic domain is unstructured in the absence of $\beta$-catenin. A possible mechanism for regulating cadherin turnover. J Biol Chem 276: 12301-12309.

Hyvönen M, Macias MJ, Nilges M, Oschkinat H, Saraste M, Wilmanns M. 1995. Structure of the binding site for inositol phosphates in a $\mathrm{PH}$ domain. EMBO J 14: 4676-4685.

Kizhatil K, Bennett V. 2004. Lateral membrane biogenesis in human bronchial epithelial cells requires 190-kDa ankyrin-G. J Biol Chem 279: 16706-16714.

Kizhatil K, Davis JQ, Davis L, Hoffman J, Hogan BL, Bennett V. 2007a. Ankyrin-G is a molecular partner of E-cadherin in epithelial cells and early embryos. J Biol Chem 282: 26552-26561.

Kizhatil K, Wu YX, Sen A, Bennett V. 2002. A new activity of doublecortin in recognition of the phospho-FIGQY tyrosine in the cytoplasmic domain of neurofascin. J Neurosci 22: 7948-7958.

Kizhatil K, Yoon W, Mohler PJ, Davis LH, Hoffman JA, Bennett V. 2007b. Ankyrin-G and $\beta 2$-spectrin collaborate in biogenesis of lateral membrane of human bronchial epithelial cells. J Biol Chem 282: 2029-2037.

Kline CF, Cunha SR, Lowe JS, Hund TJ, Mohler PJ. 2008. Revisiting ankyrin-InsP3 receptor interactions: Ankyrin$\mathrm{B}$ associates with the cytoplasmic N-terminus of the InsP3 receptor. J Cell Biochem 104: 1244-1253.

Koch I, Schwarz H, Beuchle D, Goellner B, Langegger M, Aberle H. 2008. Drosophila ankyrin-2 is required for synaptic stability. Neuron 58: 210-222. 
Kordeli E, Lambert S, Bennett V. 1995. Ankyrin-G. A new ankyrin gene with neural-specific isoforms localized at the axonal initial segment and node of Ranvier. J Biol Chem 270: 2352-2359.

Kordeli E, Ludosky MA, Deprette C, Frappier T, Cartaud J. 1998. Ankyrin-G is associated with the postsynaptic membrane and the sarcoplasmic reticulum in the skeletal muscle fiber. J Cell Sci 111: 2197-2207.

Kuhlman PA, Hughes CA, Bennett V, Fowler VM. 1996. A new function for adducin. Calcium/calmodulinregulated capping of the barbed ends of actin filaments. J Biol Chem 271: 7986-7991.

Lacas-Gervais S, Guo J, Strenzke N, Scarfone E, Kolpe M, Jahkel M, De Camilli P, Moser T, Rasband MN, Solimena M. 2004. $\beta$ IV Sigma1 spectrin stabilizes the nodes of Ranvier and axon initial segments. J Cell Biol 166: $983-990$

Lee G, Abdi K, Jiang Y, Michaely P, Bennett V, Marszalek PE. 2006. Nanospring behaviour of ankyrin repeats. Nature 440: $246-249$.

Lemaillet G, Walker B, Lambert S. 2003. Identification of a conserved ankyrin-binding motif in the family of sodium channel $\alpha$ subunits. J Biol Chem 278: 27333-27339.

Li ZP, Burke EP, Frank JS, Bennett V, Philipson KD. 1993. The cardiac $\mathrm{Na}+-\mathrm{Ca}^{2+}$ exchanger binds to the cytoskeletal protein ankyrin. J Biol Chem 268: 11489-11491.

Li X, Matsuoka Y, Bennett V. 1998. Adducin preferentially recruits spectrin to the fast growing ends of actin filaments in a complex requiring the MARCKS-related domain and a newly defined oligomerization domain. J Biol Chem 273: 19329-19338.

Littlefield RS, Fowler VM. 2008. Thin filament length regulation in striated muscle sarcomeres: Pointed-end dynamics go beyond a nebulin ruler. Semin Cell Dev Biol 19: 511-519.

Lopez C, Métral S, Eladari D, Drevensek S, Gane P, Chambrey R, Bennett V, Cartron JP, Le Van Kim C, Colin Y. 2005. The ammonium transporter RhBG: Requirement of a tyrosine-based signal and ankyrin-G for basolateral targeting and membrane anchorage in polarized kidney epithelial cells. J Biol Chem 280: 8221-8228.

Lowe JS, Palygin O, Bhasin N, Hund TJ, Boyden PA, Shibata E, Anderson ME, Mohler PJ. 2008. Voltage-gated Nav channel targeting in the heart requires an ankyrin-G dependent cellular pathway. J Cell Biol 180: 173-186.

Macias MJ, Musacchio A, Ponstingl H, Nilges M, Saraste M, Oschkinat H. 1994. Structure of the pleckstrin homology domain from $\beta$-spectrin. Nature 369: 675-677.

Maljevic S, Wuttke TV, Lerche H. 2008. Nervous system KV7 disorders: Breakdown of a subthreshold brake. J Physiol 586: 1791-1801.

Marchesi VT, Steers E Jr. 1968. Selective solubilization of a protein component of the red cell membrane. Science 159: 203-204.

Matsuoka Y, Li X, Bennett V. 1998. Adducin is an in vivo substrate for protein kinase C: Phosphorylation in the MARCKS-related domain inhibits activity in promoting spectrin-actin complexes and occurs in many cells, including dendritic spines of neurons. J Cell Biol 142: 485-497.
McKeown C, Praitis V, Austin J. 1998. sma-1 encodes a $\beta \mathrm{H}$-spectrin homolog required for Caenorhabditis elegans morphogenesis. Development 125: 2087-2098.

Michaely P, Bennett V. 1995. The ANK repeats of erythrocyte ankyrin form two distinct but cooperative binding sites for the erythrocyte anion exchanger. J Biol Chem 270: 22050-22057.

Michaely P, Tomchick DR, Machius M, Anderson RG. 2002. Crystal structure of a 12 ANK repeat stack from human ankyrin-R. EMBO J 21: 6387-6396.

Mohler PJ, Davis JQ, Bennett V. 2005. Ankyrin-B coordinates the $\mathrm{Na} / \mathrm{K}$ ATPase, $\mathrm{Na} / \mathrm{Ca}$ exchanger, and InsP3 receptor in a cardiac T-tubule/SR microdomain. PLoS Biol 3: e423.

Mohler PJ, Gramolini AO, Bennett V. 2002. The ankyrin-B C-terminal domain determines activity of ankyrin$\mathrm{B} / \mathrm{G}$ chimeras in rescue of abnormal inositol 1,4,5trisphosphate and ryanodine receptor distribution in ankyrin-B (-/-) neonatal cardiomyocytes. J Biol Chem 277: 10599-10607.

Mohler PJ, Yoon W, Bennett V. 2004a. Ankyrin-B targets $\beta 2$-spectrin to an intracellular compartment in neonatal cardiomyocytes. J Biol Chem 279: 40185-40193.

Mohler PJ, Rivolta I, Napolitano C, LeMaillet G, Lambert S, Priori SG, Bennett V. 2004c. Nav1.5 E1053K mutation causing Brugada syndrome blocks binding to ankyrin$\mathrm{G}$ and expression of Nav1.5 on the surface of cardiomyocytes. Proc Natl Acad Sci 101: 17533-17538.

Mohler PJ, Schott JJ, Gramolini AO, Dilly KW, Guatimosim S, duBell WH, Song LS, Haurogné K, Kyndt F, Ali ME, et al. 2003. Ankyrin-B mutation causes type 4 long-QT cardiac arrhythmia and sudden cardiac death. Nature 421: 634-639.

Mohler PJ, Splawski I, Napolitano C, Bottelli G, Sharpe L, Timothy K, Priori SG, Keating MT, Bennett V. 2004b. A cardiac arrhythmia syndrome caused by loss of ankyrin-B function. Proc Natl Acad Sci 101: 9137-9142.

Mosavi LK, Cammett TJ, Desrosiers DC, Peng ZY. 2004. The ankyrin repeat as molecular architecture for protein recognition. Protein Sci 13: 1435-1448.

Muresan V, Stankewich MC, Steffen W, Morrow JS, Holzbaur EL, Schnapp BJ. 2001. Dynactin-dependent, dynein-driven vesicle transport in the absence of membrane proteins: A role for spectrin and acidic phospholipids. Mol Cell 7: 173-183.

Musacchio A, Noble M, Pauptit R, Wierenga R, Saraste M. 1992. Crystal structure of a Src-homology 3 (SH3) domain. Nature 359: 851-855.

Nelson WJ, Veshnock PJ. 1986. Dynamics of membraneskeleton (fodrin) organization during development of polarity in Madin-Darby canine kidney epithelial cells. J Cell Biol 103: 1751-1765.

Nelson WJ, Veshnock PJ. 1987. Ankyrin binding to $(\mathrm{Na}++\mathrm{K}+)$ ATPase and implications for the organization of membrane domains in polarized cells. Nature 328: $533-536$.

Neubauer BA, Waldegger S, Heinzinger J, Hahn A, Kurlemann G, Fiedler B, Eberhard F, Muhle H, Stephani U, Garkisch S, et al. 2008. KCNQ3 mutations contribute to different idiopathic epilepsy syndromes. Neurology 71: 177-183. 
V. Bennett and J. Healy

Nicolas V, Le Van Kim C, Gane P, Birkenmeier C, Cartron JP, Colin Y, Mouro-Chanteloup I. 2003. Rh-RhAG/ankyrin$\mathrm{R}$, a new interaction site between the membrane bilayer and the red cell skeleton, is impaired by $\mathrm{Rh}$ (null)associated mutation. J Biol Chem 278: 25526-25533.

Ogawa Y, Schafer DP, Horresh I, Bar V, Hales K, Yang Y, Susuki K, Peles E, Stankewich MC, Rasband MN. 2006. Spectrins and ankyrin-B constitute a specialized paranodal cytoskeleton. J Neurosci 26: 5230-5239.

Otsuka AJ, Franco R, Yang B, Shim KH, Tang LZ, Zhang YY, Boontrakulpoontawee P, Jeyaprakash A, Hedgecock E, Wheaton VI. 1995. An ankyrin-related gene (unc-44) is necessary for proper axonal guidance in Caenorhabditis elegans. J Cell Biol 129: 1081-1092.

Pan Z, Kao T, Horvath Z, Lemos J, Sul JY, Cranstoun SD, Bennett V, Scherer SS, Cooper EC. 2006. A common ankyrin-G-based mechanism retains KCNQ and NaV channels at electrically active domains of the axon. $J$ Neurosci 26: 2599-2613.

Pardo JV, Siliciano JD, Craig SW. 1983. A vinculincontaining cortical lattice in skeletal muscle: Transverse lattice elements ("costameres") mark sites of attachment between myofibrils and sarcolemma. Pro Natl Acad Sci 80: $1008-1012$.

Pariser H, Herradon G, Ezquerra L, Perez-Pinera P, Deuel TF. 2005. Pleiotrophin regulates serine phosphorylation and the cellular distribution of $\beta$-adducin through activation of protein kinase C. Pro Natl Acad Sci 102: 12407-12412.

Pascual J, Castresana J, Saraste M. 1997. Evolution of the spectrin repeat. Bioessays 19: 811-817.

Pielage J, Fetter RD, Davis GW. 2005. Presynaptic spectrin is essential for synapse stabilization. Curr Biol 15: 918-928.

Pielage J, Fetter RD, Davis GW. 2006. A postsynaptic spectrin scaffold defines active zone size, spacing, and efficacy at the Drosophila neuromuscular junction. J Cell Biol 175: 491-503.

Pielage J, Cheng L, Fetter RD, Carlton PM, Sedat JW, Davis GW. 2008. A presynaptic giant ankyrin stabilizes the NM] through regulation of presynaptic microtubules and transsynaptic cell adhesion. Neuron 58: 195-209.

Rasmussen HB, Frøkjaer-Jensen C, Jensen CS, Jensen HS, Jørgensen NK, Misonou H, Trimmer JS, Olesen SP, Schmitt N. 2007. Requirement of subunit co-assembly and ankyrin-G for M-channel localization at the axon initial segment. J Cell Sci 120: 953-963.

Rybakova IN, Patel JR, Ervasti JM. 2000. The dystrophin complex forms a mechanically strong link between the sarcolemma and costameric actin. J Cell Biol 150: 1209-1214.

Rotin D, Bar-Sagi D, O'Brodovich H, Merilainen J, Lehto VP, Canessa CM, Rossier BC, Downey GP. 1994. An SH3 binding region in the epithelial $\mathrm{Na}+$ channel $(\alpha$ $\mathrm{rENaC}$ ) mediates its localization at the apical membrane. EMBO J 13: 4440-44450.

Sakaguchi G, Orita S, Naito A, Maeda M, Igarashi H, Sasaki T, Takai Y. 1998. A novel brain-specific isoform of $\beta$ spectrin: Isolation and its interaction with Munc13. Biochem Biophys Res Commun 248: 846-851.

Scriven DR, Dan P, Moore ED. 2000. Distribution of proteins implicated in excitation-contraction coupling in rat ventricular myocytes. Biophys J 79: 2682-2691.
Shaw RM, Fay AJ, Puthenveedu MA, von Zastrow M, Jan YN, Jan LY. 2007. Microtubule plus-end-tracking proteins target gap junctions directly from the cell interior to adherens junctions. Cell 128: 547-560.

Shotton DM, Burke BE, Branton D. 1979. The molecular structure of human erythrocyte spectrin. Biophysical and electron microscopic studies. J Mol Biol 131: 303-329.

Simonovic M, Zhang Z, Cianci CD, Steitz TA, Morrow JS. 2006. Structure of the calmodulin $\alpha$ II-spectrin complex provides insight into the regulation of cell plasticity. $J$ Biol Chem 281: 34333-34340.

Sohet F, Colin Y, Genetet S, Ripoche P, Métral S, Le Van Kim C, Lopez C. 2008. Phosphorylation and ankyrin-G binding of the $\mathrm{C}$-terminal domain regulate targeting and function of the ammonium transporter RhBG. $J$ Biol Chem 283: 26557-26567.

Speicher DW, Marchesi VT. 1984. Erythrocyte spectrin is comprised of many homologous triple helical segments. Nature 311: 177-180.

Srinivasan Y, Elmer L, Davis J, Bennett V, Angelides K. 1988. Ankyrin and spectrin associate with voltage-dependent sodium channels in brain. Nature 333: 177-180.

Stabach PR, Morrow JS. 2000. Identification and characterization of $\beta V$ spectrin, a mammalian ortholog of Drosophila $\beta$ H spectrin. J Biol Chem 275: 21385-21395.

Stabach PR, Simonović I, Ranieri MA, Aboodi MS, Steitz TA, Simonović M, Morrow JS. 2009. The structure of the ankyrin-binding site of $\beta$-spectrin reveals how tandem spectrin-repeats generate unique ligand-binding properties. Blood 113: 5377-5384.

Stankewich MC, Tse WT, Peters LL, Ch'ng Y, John KM, Stabach PR, Devarajan P, Morrow JS, Lux SE. 1998. A widely expressed $\beta$ III spectrin associated with Golgi and cytoplasmic vesicles. Proc Natl Acad Sci 95: 14158-14163.

Stefanovic M, Markham NO, Parry EM, Garrett-Beal LJ, Cline AP, Gallagher PG, Low PS, Bodine DM. 2007. An 11 -amino acid $\beta$-hairpin loop in the cytoplasmic domain of band 3 is responsible for ankyrin binding in mouse erythrocytes. Proc Natl Acad Sci 104: 13972-13977.

Steiner D, Forrer P, Plückthun A. 2008. Efficient selection of DARPins with sub-nanomolar affinities using SRP phage display. J Mol Biol 382: 1211-1227.

Stumpp MT, Amstutz P. 2007. DARPins: A true alternative to antibodies. Curr Opin Drug Discov Devel 10: 153-159.

Sunderland WJ, Son YJ, Miner JH, Sanes JR, Carlson SS. 2000. The presynaptic calcium channel is part of a transmembrane complex linking a synaptic laminin $(\alpha 4 \beta 2 \gamma 1)$ with non-erythroid spectrin. J Neurosci 20: 1009-1019.

Takeda S, Yamazaki H, Seog DH, Kanai Y, Terada S, Hirokawa N. 2000. Kinesin superfamily protein 3 (KIF3) motor transports fodrin-associating vesicles important for neurite building. J Cell Biol 148: 1255-1265.

Thomas GH, Newbern EC, Korte CC, Bales MA, Muse SV, Clark AG, Kiehart DP. 1997. Intragenic duplication and divergence in the spectrin superfamily of proteins. $\mathrm{Mol}$ Biol Evol 14: 1285-1295. 
Thomas GH, Zarnescu DC, Juedes AE, Bales MA, Londergan A, Korte CC, Kiehart DP. 1998. Drosophila $\beta$ Heavy-spectrin is essential for development and contributes to specific cell fates in the eye. Development 125: $2125-2134$

Travé G, Pastore A, Hyvönen M, Saraste M. 1995. The C-terminal domain of $\alpha$-spectrin is structurally related to calmodulin. Eur J Biochem 227: 35-42.

Voas MG, Lyons DA, Naylor SG, Arana N, Rasband MN Talbot WS. 2007. $\alpha$ II-spectrin is essential for assembly of the nodes of Ranvier in myelinated axons. Curr Biol 17: $562-568$.

Waters J, Schaefer A, Sakmann B. 2005. Backpropagating action potentials in neurones: Measurement, mechanisms and potential functions. Prog Biophys Mol Biol 87: $145-170$.

Weber KL, Fischer RS, Fowler VM. 2007. Tmod3 regulates polarized epithelial cell morphology. J Cell Sci 120: 3625-3632.

Wechsler A, Teichberg VI. 1998. Brain spectrin binding to the NMDA receptor is regulated by phosphorylation, calcium and calmodulin. EMBO J 17: 3931-3939.

Whittard JD, Sakurai T, Cassella MR, Gazdoiu M, Felsenfeld DP. 2006. MAP kinase pathway-dependent phosphorylation of the L1-CAM ankyrin binding site regulates neuronal growth. Mol Biol Cell 17: 2696-2706.

Wood SJ, Slater CR. 1998. $\beta$-Spectrin is colocalized with both voltage-gated sodium channels and ankyrin-G at the adult rat neuromuscular junction. J Cell Biol 140: 675-684.

Xu M, Cao R, Xiao R, Zhu MX, Gu C. 2007. The axondendrite targeting of Kv3 (Shaw) channels is determined by a targeting motif that associates with the $\mathrm{T} 1$ domain and ankyrin-G. J Neurosci 27: 14158-14170.

Yang Y, Ogawa Y, Hedstrom KL, Rasband MN. 2007. ßIV spectrin is recruited to axon initial segments and nodes of Ranvier by ankyrin-G. J Cell Biol 176: 509-519.

Zhang X, Davis JQ, Carpenter S, Bennett V. 1998. Structural requirements for association of neurofascin with ankyrin. J Biol Chem 273: 30785-30794.

Zhang P, Talluri S, Deng H, Branton D, Wagner G. 1995. Solution structure of the pleckstrin homology domain of Drosophila $\beta$-spectrin. Structure 3: 1185-1195.

Zhou D, Birkenmeier CS, Williams MW, Sharp JJ, Barker JE Bloch RJ. 1997. Small, membrane-bound, alternatively spliced forms of ankyrin 1 associated with the sarcoplasmic reticulum of mammalian skeletal muscle. J Cell Biol 136: 621-631.

Zhou D, Lambert S, Malen PL, Carpenter S, Boland LM, Bennett V. 1998. Ankyrin-G is required for clustering of voltage-gated $\mathrm{Na}$ channels at axon initial segments and for normal action potential firing. J Cell Biol 143: 1295-1304.

Zuckerman JB, Chen X, Jacobs JD, Hu B, Kleyman TR, Smith PR. 1999. Association of the epithelial sodium channel with Apx and $\alpha$-spectrin in A6 renal epithelial cells. J Biol Chem 274: 23286-23295. 


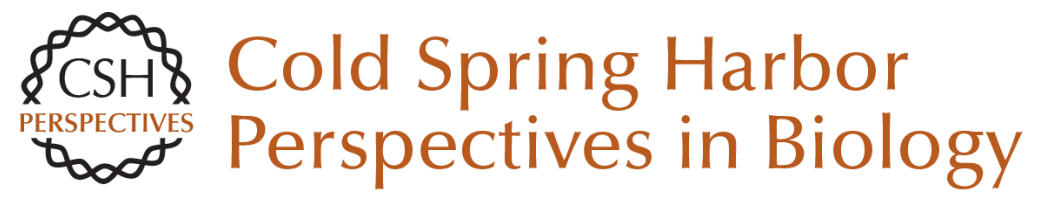

\title{
Membrane Domains Based on Ankyrin and Spectrin Associated with Cell-Cell Interactions
}

\author{
Vann Bennett and Jane Healy
}

Cold Spring Harb Perspect Biol 2009; doi: 10.1101/cshperspect.a003012 originally published online August 19, 2009

\section{Subject Collection Cell-Cell Junctions}

Vascular Endothelial (VE)-Cadherin, Endothelial

Adherens Junctions, and Vascular Disease Maria Grazia Lampugnani, Elisabetta Dejana and Costanza Giampietro

Adherens Junctions and Desmosomes Coordinate Mechanics and Signaling to Orchestrate Tissue Morphogenesis and Function: An Evolutionary Perspective Matthias Rübsam, Joshua A. Broussard, Sara A. Wickström, et al.

Cell-Cell Contact and Receptor Tyrosine Kinase Signaling Christine Chiasson-MacKenzie and Andrea I. McClatchey

Hold Me, but Not Too Tight--Endothelial Cell-Cell Junctions in Angiogenesis

Anna Szymborska and Holger Gerhardt

Connexins and Disease

Mario Delmar, Dale W. Laird, Christian C. Naus, et al.

Cell Junctions in Hippo Signaling Ruchan Karaman and Georg Halder
Signaling by Small GTPases at Cell-Cell Junctions: Protein Interactions Building Control and Networks

Vania Braga

Making Connections: Guidance Cues and

Receptors at Nonneural Cell-Cell Junctions Ian V. Beamish, Lindsay Hinck and Timothy E. Kennedy

The Cadherin Superfamily in Neural Circuit Assembly James $D$. Jontes

Mechanosensing and Mechanotransduction at Cell-Cell Junctions Alpha S. Yap, Kinga Duszyc and Virgile Viasnoff

Beyond Cell-Cell Adhesion: Sensational

Cadherins for Hearing and Balance Avinash Jaiganesh, Yoshie Narui, Raul Araya-Secchi, et al.

Cell-Cell Junctions Organize Structural and Signaling Networks Miguel A. Garcia, W. James Nelson and Natalie Chavez

For additional articles in this collection, see http://cshperspectives.cshlp.org/cgi/collection/

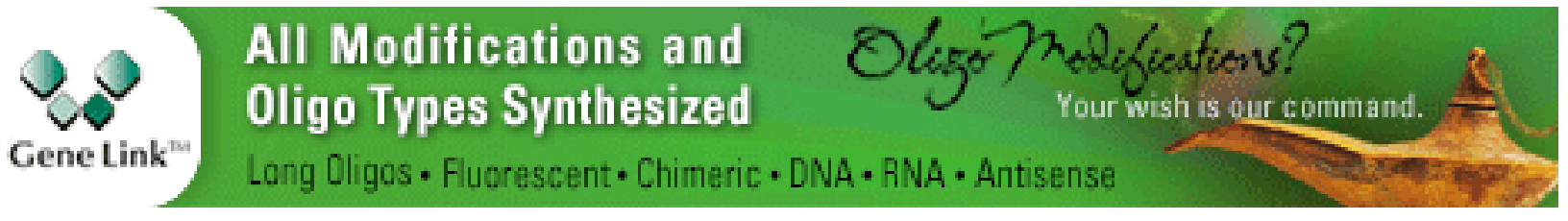


Loss of E-Cadherin-Dependent Cell-Cell Adhesion and the Development and Progression of Cancer Heather C. Bruner and Patrick W.B. Derksen

Desmosomes and Intermediate Filaments: Their Consequences for Tissue Mechanics

Mechthild Hatzfeld, René Keil and Thomas M. Magin
Cell Biology of Tight Junction Barrier Regulation and Mucosal Disease

Aaron Buckley and Jerrold R. Turner

Integration of Cadherin Adhesion and

Cytoskeleton at Adherens Junctions

René Marc Mège and Noboru Ishiyama

For additional articles in this collection, see http://cshperspectives.cshlp.org/cgi/collection/

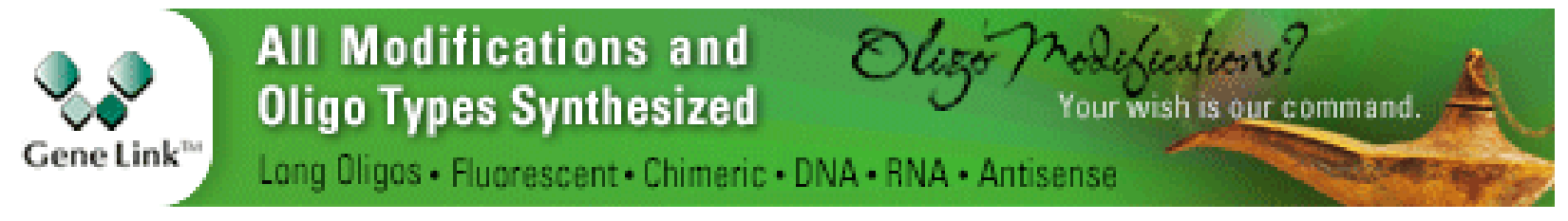

Copyright @ 2009 Cold Spring Harbor Laboratory Press; all rights reserved 